ISSN 1392-3196 / e-ISSN 2335-8947

Zemdirbyste-Agriculture, vol. 106, No. 4 (2019), p. 359-366

DOI 10.13080/z-a.2019.106.046

\title{
Application of marker-assisted selection for resistance to gall mite and Blackcurrant reversion virus in Ribes genus
}

\author{
Ingrida MAZEIKIENE ${ }^{1}$, Ana Dovile JUSKYTE ${ }^{1}$, Vidmantas STANYS ${ }^{1,2}$ \\ ${ }^{1}$ Lithuanian Research Centre for Agriculture and Forestry, Institute of Horticulture \\ Kauno 30, Babtai, Kaunas distr., Lithuania \\ E-mail: i.mazeikiene@1sdi.lt \\ ${ }^{2}$ Vytautas Magnus University, Agriculture Academy \\ Studentų 11, Akademija, Kaunas distr., Lithuania
}

\begin{abstract}
Gall mite (Cecidophyopsis ribis Westw.) is a biological vector of Blackcurrant reversion virus (BRV), and both are widespread in the countries, where blackcurrants are cultivated commercially. Blackcurrant (Ribes nigrum L.) is the primary natural host of BRV, although natural infestations also occur in other Ribes spp. Some Ribes species and cultivars are resistant to $C$. ribis and/or BRV. The mechanism and gene structure of resistance are not clear, that is why molecular markers for breeding of resistant blackcurrants are still in the process of searching. Several molecular markers related to resistance to the pathogen and pest in Ribes spp. genotypes were identified by quantitative trait loci (QTL) mapping. These molecular markers can be used for acceleration of the breeding process of resistant blackcurrant, because phenotyping in the field is unnecessary. In our study, the presence of the 12 polymerase chain reaction (PCR) markers, amplified fragment length polymorphism (AFLP) and single sequence repeat (SSR), linked to gall mite and virus resistance loci from 4 to $20 \mathrm{cM}$ were analysed. Eleven of them demonstrated suitability for selection of resistant genotypes in this study. The presence of these molecular markers in 8 Ribes species, 15 hybrids and $13 R$. nigrum cultivars was shown. Fully specific molecular marker for detection of genotypes with resistance to gall mite and virus among Ribes species was not found. The complex application of eleven molecular markers allowed for significant grouping of Ribes species, cultivars and hybrids with different genetic origin of resistance to pest and virus. As well, they can be useful for marker-assisted selection. Six molecular markers: E36M59_107, E40M43_236, E40M43_289, E40M40_219, E41M88_280 and E45M40_222, were distinguished as more suitable for identifying resistant Ribes spp. genotypes with $\overline{C e}$ and $P$ genes in this study.
\end{abstract}

Key words: gall mite, molecular marker, resistance.

\section{Introduction}

Blackcurrant reversion disease (BRD) is economically the most significant virus disease in Ribes species. Blackcurrant reversion virus (BRV) is the causal agent of BRD (De Lillo et al., 2018). BRV is the first identified mite-transmitted member of the genus Nepovirus. The gall mite (Cecidophyopsis ribis) is a biological vector of BRV (Martin, Tzanetakis, 2015). Wild species are mostly used for the introgression of disease resistance genes. The natural host range of BRV is limited. $R$. nigrum is the primary natural host for both C. ribis and BRV, although natural infestations occur also in some related Ribes species: $R$. rubrum, R. brasteosum and $R$. spicatum. In general, they are hardly used to improve quantitative traits in breeding programs. Resistance or even immunity to the blackcurrant reversion agent has been identified in $R$. aureum,

$R$. cereum, R.fuscescens, R. gordonianum, R. dikushka, $R$. nigrum ssp. sibiricum, R. pauciflorum and $R$. uvacrispa (Brennan, 2008; Stalažs, Moročko-Bičevska, 2016; De Lillo et al., 2018). Gene Ce, responsible for resistance to gall mite and BRV was established in gooseberries (Keep et al., 1982). Another gene $P$ is derived from $R$. nigrum ssp. sibiricum and responsible for genetic resistance to gall mite, thereby preventing viral infection in plant (Andersson, 1971).

The quantitative trait loci (QTL) as markerassisted selection (MAS) in plant breeding programs are successfully applied. A wide range of DNA-based markers have been developed as well as procedures are getting simpler and cheaper. Nuclear based single sequence repeat (SSR) and amplified fragment length polymorphism (AFLP) are some of the commonly

Please use the following format when citing the article:

Mažeikienė I., Juškytė A. D., Stanys V. 2019. Application of marker-assisted selection for resistance to gall mite and Blackcurrant reversion virus in Ribes genus. Zemdirbyste-Agriculture, 106 (4): 359-366. DOI 10.13080/z-a.2019.106.046 
used markers for genome and QTL mapping in order to understand the evolutionary genetics and sequences controlling traits (Brennan et al., 2008). Instead of inferring marker-assisted selection schemes in breeding populations from QTL results in bi-parental populations, the development of QTL mapping methods for multiparental populations is envisaged as a better alternative. It would allow linking QTL analysis and marker-assisted selection in tandem through generations in the breeding programs (Asins et al., 2010; Ahmad et al., 2017). It is therefore of interest to breed blackcurrant cultivars not only with high nutritional value (high concentrations of phenolic compounds and vitamin C), but also with natural resistance against diseases and pests (Hummer, Dale, 2010).

Genome studies of Ribes species of these small fruit plants are still limited. AFLP, single nucleotide polymorphism (SNP) and SSR molecular markers for genotyping, QTL mapping and identification of regions associated with morphological traits have been investigated (Brennan et al., 2008; Russell et al., 2011; Mazeikiene et al., 2012; Palmieri et al., 2013). SNP, AFLP and SSR markers related with resistance to gall mite and other phenological and morphological traits in Ribes spp. hybrids were analysed. The second generation sequencing based on transcriptome is the approach extremely cost-effective for species with unsequenced genomes; however, informatic analysis of such data is still in its infancy (Russell et al., 2011). AFLP markers related to genes $\mathrm{Ce}$ (Brennan et al., 2009) and $P$ (Mazeikiene et al., 2012) are suggested at this time. Consequently, bi-parental populations were used to make QTL, these markers are not significantly reliable for the evaluation of various Ribes species (Mazeikiene et al., 2017), but due to the similarity of genetic resistance mechanisms in plants, they could be applied. Resistance to the gall mite can be associated with several other molecular markers according to QTL data (Brennan et al., 2008; 2009). Their suitability can be studied in the breeding of resistant Ribes spp. genotypes for marker-assisted selection.

The aim of our study is to evaluate the suitability of molecular markers related to gall mite resistance in QTLs for marker-assisted selection of resistant Ribes spp. genotypes.

\section{Materials and methods}

The study was conducted at the Institute of Horticulture of Lithuanian Research Centre for Agriculture and Forestry in 2018.

Plant material and DNA isolation. All investigated blackcurrant (Ribes nigrum L.) plants are grown at a collection of Institute of Horticulture $\left(55^{\circ} 60^{\prime} \mathrm{N}, 23^{\circ} 48^{\prime} \mathrm{E}\right)$, Lithuanian Research Centre for Agriculture and Forestry. Thirteen cultivars - resistant 'Aldoniai', 'Dainiai', 'Domino', 'Minaj Šmyriov', 'Ritmo', 'Senjorai', 'Smaliai', 'Viktor' and susceptible 'Tauriai', 'Titania', 'Gojai', 'Katiusha', 'Vernisaz', eight Ribes species - R. americanum Mill., R. aureum 'Brecht' Pursh, R. dikuscha Fisch., R. nigrum ssp. sibiricum Pavl., $R$. pauciflorum Turcz., R. sanguineum Pursh, R. uvacrispa L., $R$. hudsonianum Richardson, and fifteen intra or inter species hybrids with different resistance to gall mite according to the data in field conditions was analysed (Table 1).

Table 1. Crossing components of Ribes spp. hybrids and resistance to gall mite in field conditions

\begin{tabular}{|c|c|c|}
\hline $\begin{array}{c}\text { Hybrid } \\
\text { No. }\end{array}$ & Crossing components & $\begin{array}{l}\text { Resistance to } \\
\text { gall mite in } \\
\text { field conditions }\end{array}$ \\
\hline Hybrid 1 & 'Tauriai' x 'Vernisaz-1' & resistant \\
\hline Hybrid 2 & 'Gojai' × 'Ruben-1' & resistant \\
\hline Hybrid 3 & ('Ben Lomond' × 'Ben Gain') $\times$ 'Dainiai' & resistant \\
\hline Hybrid 4 & R. nigrum $\times R$. uva-crispa 'Josta' & resistant \\
\hline Hybrid 5 & $\begin{array}{l}(R . \text { nigrum } \times R \text {. americanum }) \times \\
\left(\text { 'Titania' } \times R . \text { uva-crispa 'Bedford Yellow') } \mathrm{F}_{2}\right.\end{array}$ & resistant \\
\hline Hybrid 6 & 'Ben Tirran' $\times$ R. usuriensis $\mathrm{F}_{2}$ & resistant \\
\hline Hybrid 7 & 'Titania' $\times$ R. rubrum 'Jonkher van Tets' $\mathrm{F}_{3}$ & resistant \\
\hline Hybrid 8 & 'Tauriai' $\times\left(\right.$ 'Titania' $\times$ R. uva-crispa 'Bedford Yellow') $\mathrm{F}_{2}$ & resistant \\
\hline Hybrid 9 & 'Triton' $\times$ R. rubrum 'Rondom' $\mathrm{F}_{2}$ & susceptible \\
\hline Hybrid 10 & 'Titania $\times$ R. uva-crispa 'Kuršu Dzintars' $\mathrm{F}_{2}$ & susceptible \\
\hline Hybrid 11 & 'Vakariai’ $\times R$. janczewskii $\mathrm{F}_{1}$ & susceptible \\
\hline Hybrid 12 & PC73 $\times R$. usuriensis $\mathrm{F}_{2}$ & susceptible \\
\hline Hybrid 13 & $(' B e n$ Lomond' $\times$ BRi 8315-25) $\times$ 'Tauriai-40' & susceptible \\
\hline Hybrid 14 & 'Tauriai' x 'Vernisaz-2' & susceptible \\
\hline Hybrid 15 & 'Gojai' × 'Ruben-8' & susceptible \\
\hline
\end{tabular}

Total DNA of the tested genotypes was extracted from $0.2 \mathrm{mg}$ fresh leaves using the modified cetyltrimethylammonium bromide (CTAB) - based extraction protocol by Doyle and Doyle (1990). After extraction, DNA was additionally cleaned with $10 \mathrm{M}$ $\mathrm{LiCl}$ solution.

Identification of polymerase chain reaction $(P C R)$ markers. Eleven amplified fragment length 
polymorphism (AFLP) and one single sequence repeat (SSR) marker from three linkage maps (Brennan et al., 2008; 2009; Mazeikiene et al., 2012) were chosen according to association with gall mite morphologic traits (Table 2). AFLP and SSR analysis was ere used for detection of molecular markers.

AFLP analysis was performed according to Vos et al. (1995) method. Samples were prepared using AFLP Plant Fingerprinting Kit (Applied Biosystems, USA). The AFLP template was prepared with restriction endonucleases EcoRI and MseI (Thermo Scientific Ltd.).
Ligation, preamplification and selective amplification of samples was performed according to Brennan et al. (2009) and Mazeikiene et al. (2012). Forward primer of loci g2JO8 was labelled with fluorochrome 6-carboxyfluorescein (6FAM) for SSR analysis. Amplification was performed using conditions described by Mazeikiene et al. (2017). For capillary electrophoresis, each PCR product was diluted with 10 times deionised formamide solution containing GeneScan-500 LIZ ladder and analysed using a 3130 Genetic Analyser (Applied Biosystems).

Table 2. Methods and primer pairs used for detection of molecular markers according to distance data (cM) in linkage group (LG) from gall mite resistance (GMres) in field conditions

\begin{tabular}{|c|c|c|c|}
\hline $\begin{array}{c}\text { Code of primer pair / } \\
\text { used method for } \\
\text { molecular marker obtaining }\end{array}$ & $\begin{array}{l}\text { Primer } \\
\text { pair }\end{array}$ & $\begin{array}{l}\text { Fragment size } \\
\text { bp }\end{array}$ & $\begin{array}{c}\text { Distance in } \mathrm{LG} \\
\text { from GMres, } \\
\mathrm{cM}\end{array}$ \\
\hline E36M59 / AFLP & EcoRI ACC - MseI CTA & 107 & $14^{3}$ \\
\hline E40M40 / AFLP & EcoRI AGC - MseI AGC & 219 & $10^{1,2}$ \\
\hline E40M41 / AFLP & EcoRI AGC - MseI AGG & 121 & $4^{1}$ \\
\hline E40M42 / AFLP & EcoRI AGC - MseI AGT & 226 & $9^{1,2}$ \\
\hline E40M43 / AFLP & $E c o$ RI AGC - MseI ATA & 236 & $4^{1}, 14^{2}$ \\
\hline E40M43 / AFLP & EcoRI AGC - MseI ATA & 289 & $11^{2}, 12^{1}$ \\
\hline E41M40 / AFLP & EcoRI AGG - MseI AGC & 222 & $5^{1}$ \\
\hline E41M41 / AFLP & EcoRI AGG-MseI AGG & 163 & $7^{1}, 11^{2}$ \\
\hline E41M43 / AFLP & $E c o$ RI AGG - MseI ATA & 179 & $7^{1}, 8^{2}$ \\
\hline E41M88 / AFLP & EcoRI AGG - MseI TGC & 280 & $4^{2}$ \\
\hline E45M40 / AFLP & EcoRI ATG - MseI AGC & 222 & $4^{1}, 20^{2}$ \\
\hline g2-JO8 / SSR & $\begin{array}{l}\text { 5'CGC CGA GCT CTA ATC ACT GT3' } \\
\text { 5'ATA GCC CAT GCC CAT ATT CA3' }\end{array}$ & 166 & $7^{2}, 9^{1}$ \\
\hline
\end{tabular}

Linkage map data according to ${ }^{1}$ Brennan et al., 2008, ${ }^{2}$ Brennan et al., 2009 and ${ }^{3}$ Mazeikiene et al., 2012

Statistical analysis. The identification of AFLP and SSR molecular markers by size of base pair (bp) (Table 2) was performed with the programme GeneMapper, version 4.0 (Applied Biosystems). Data of PCR markers frequency was evaluated by the analysis of variance (ANOVA) from the package Selekcija (Raudonius, 2017). Heterogeneity between distribution frequencies: molecular markers and morphologic resistance to gall mite and Blackcurrant reversion virus (BRV), among 36 Ribes spp. genotypes was examined using the Chi-square test or among 11 molecular markers using the dissimilarity between units. Phylogenetic trees were constructed based on unweighted neighbour-joining grouping method in the software package DarWin, version 6.0.10 (Perrier, Jacquemoud-Collet, http:// darwin.cirad.fr/darwin); a bootstrap analysis with 1000 replications was performed.

\section{Results and discussion}

Among all investigated Ribes spp. genotypes, 102 fragments associated with molecular markers linked to gall mite resistance were amplified. Frequency of molecular markers ranged from $11.1 \%$ to $33.3 \%$ in resistant Ribes spp. genotypes to gall mite and/or BRV and to $19.4 \%$ in susceptible genotypes according to results obtained by the programme GeneMapper. The E40M41 121 marker in QTL map linking group (LG) 2 was at $4 \mathrm{cM}$ distance from the phenotypic resistance based on gene Ce (Brennan et al., 2008). The study revealed that presence of E40M41_121 molecular marker in resistant genotypes was $25.0 \%$, in susceptible genotypes $-19.4 \%$. We removed E40M41 121 marker from further data analysis, because it is inappropriate for gal mite and BRV resistance. Low frequency of AFLP markers E40M43_236 and E41M40_222 among susceptible genotypes was detected once and that of markers E40M42 219 and E45M40 222 - twice (data not shown).

Molecular markers E36M59_107 (frequency $75 \%$ ) and E40M43 289 (frequency 50.0\%) were detected in resistant to gall mite and BRV genotypes (Fig. 1). These molecular markers were not found in BRV resistant genotypes. It is known that PCR fragment E36M59 107 is a molecular marker of gene $P$ (Mazeikiene et al., 2012). DNA fragment E40M43 289 can be used as a marker of resistance to gall mite also. PCR markers E4043_236, E41M40_222, E41M41_163, E41M43 179, E41M88 280, E40M40-219, E40M42_226, E45M40_222 and g2-J08 were identified in resistant to gall mite and BRV Ribes spp. genotypes as well in genotypes only with virus resistance. These amplified fragments might identify genotypes that are resistant to the virus as well as molecular marker E41M88 280 suggested by Brennan's and colleagues (2009). Markers shown in Figure 1 jointly could be useful for marker-assisted selection without phenotypic evaluation in Ribes species. 


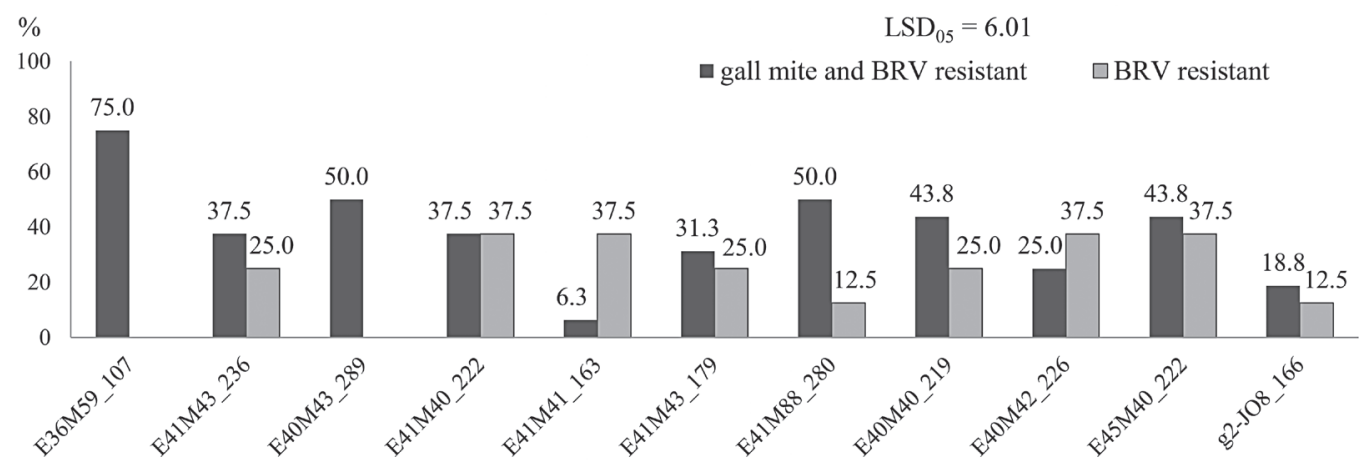

Figure 1. Frequency of molecular markers related to resistance to gall mite and/or Blackcurrant reversion virus (BRV) in resistant Ribes spp. genotypes

The phylogenetic tree of Ribes spp. cultivars, species and hybrids with different genetic resistance was constructed using the data of eleven PCR markers related to resistance to gall mite and reversion virus. Ribes spp. genotypes constitute three groups depending on the inherited molecular markers. Distinct cluster with significant difference (at 50\% bootstrap) of susceptible Ribes spp. cultivars to gall mite and BRV was grouped in the separate branch, which was circumscribed in Figure 2.
It was established that 'Titania', 'Tauriai', 'Vernisaz', 'Gojai', 'Katiusha' and seven inter and intra hybrids were highly susceptible to gall mite and BRV in field conditions according to our and other authors' data (Šikšnianas, 2005; Rubauskis et al., 2006; Siksnianas et al., 2006). Resistant genotypes constitute three groups depending on the inherited molecular markers. Low susceptibility to gall mite is known for $R$. hudsonianum and cultivar 'Smaliai', but they are completely BRV resistant (Šikšnianas, 2005; Brennan, 2008). These genotypes are

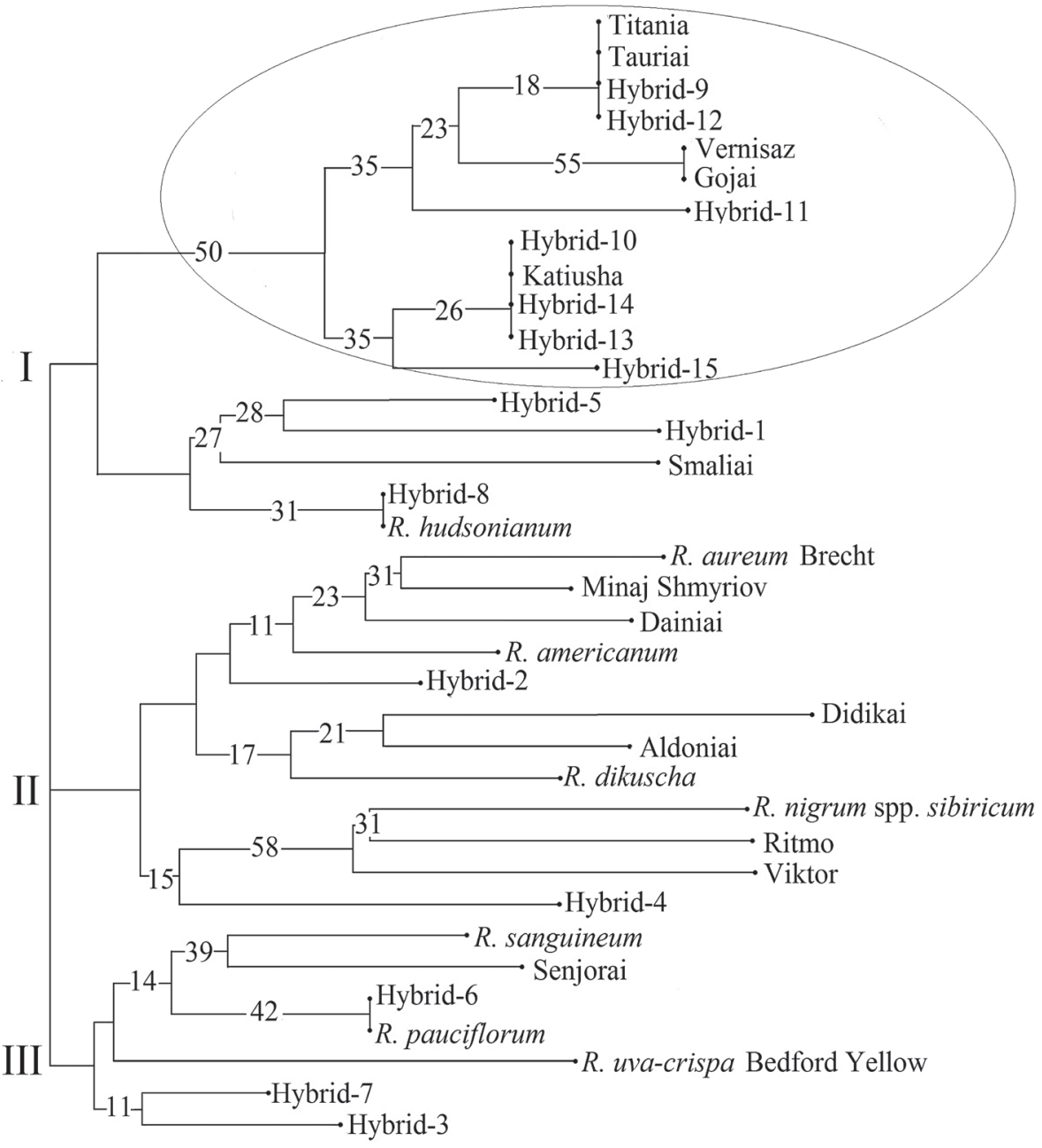

Note. Susceptible genotypes are framed in the circle.

Figure 2. Phylogenetic tree based on neighbour-joining unweighted analysis generated using the Chi-square test representing the relationships of Ribes spp. genotypes based on 11 molecular markers linked to resistance to Cecidophyopsis ribis and Blackcurrant reversion virus (BRV) 
located in the first branch of the phylogenetic tree and represent blackcurrants with low susceptibility to gall mite and resistance to virus. The second branch consisted of genotypes with full genetic resistance, which in most cases is determined by gene $P$. Cultivars located in this branch 'Minaj Shmyriov', 'Dainiai', 'Didikai', 'Aldoniai', 'Ritmo' and 'Viktor' have resistance to gall mite and its transmitted BRV, determined by gene $P$ as in $R$. nigrum ssp. sibiricum and $R$. americanum. Gall mite resistant hybrids show distorted segregation at expected Mendelian ratio 1:1 in hybrids of bi-parental families when one parent is with dominant gene of resistance (Mazeikiene et al., 2017). Presence of molecular markers in intra species hybrids 'Tauriai' $\times$ Vernisaz-1' and 'Gojai' $\times$ 'Ruben-1' and absence in 'Tauriai' $\times$ 'Vernisaz-2' and 'Gojai' $\times$ 'Ruben- 8 ' demonstrate different resistance of these genotypes derived from 'Tauriai' (Šikšnianas, 2005) and 'Ruben' (Piotrowski et al., 2016). Genotypes with resistance determined by gene $\mathrm{Ce}$ were branched in the third group of phylogenetic tree. The presence of $R$. uva-crispa and $R$. sanguineum as donors of gene Ce (Brennan et al., 2009; Mazeikiene et al., 2017) proves the statement mentioned before. A complex study of eleven molecular markers correctly identifies resistant Ribes spp. cultivars, species and hybrids to gall mite and BRV in short time.

Ribes spp. genotypes with resistance to gall mite or BRV in field conditions and presence or absence of molecular markers are shown in Table 3. Presence of molecular markers varied between 4 and 8 in $R$. nigrum cultivars. Eight molecular markers were found in 'Didikai' genome. It is a new cultivar with a rich pedigree, combining features from three Ribes spp. genomes (Mažeikienè et al., 2017). Other Lithuanian cultivars are also characterized by a large number of resstance molecular markers.

Table 3. Presence of molecular markers in Ribes spp. genotypes with resistance to gall mite (GM) and Blackcurrant reversion virus (BRV)

\begin{tabular}{|c|c|c|c|c|c|c|c|c|c|c|c|c|}
\hline \multirow[b]{2}{*}{$\begin{array}{l}\text { Genotype resistant to } \\
\text { gall mite and/or virus }\end{array}$} & \multicolumn{11}{|c|}{ Molecular markers } & \multirow[b]{2}{*}{ Tota } \\
\hline & $\begin{array}{l}\hat{o} \\
\sum_{1}^{\prime} \\
\sum_{0}^{n} \\
\text { II }\end{array}$ & 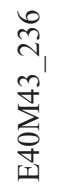 & 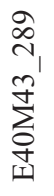 & 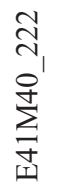 & 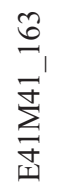 & 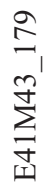 & 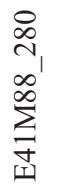 & 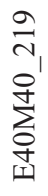 & 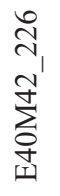 & 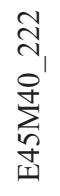 & $\begin{array}{l}0 \\
\stackrel{0}{0} \\
\infty \\
0 \\
0 \\
\dot{0} \\
\dot{0}\end{array}$ & \\
\hline 'Aldoniai' (GM, BRV) & $x$ & $x$ & & & & & $x$ & $x$ & & $x$ & & 5 \\
\hline ‘Dainiai’ (GM, BRV) & $x$ & & $x$ & $x$ & & & $\times$ & $\times$ & & $\times$ & & 6 \\
\hline 'Didikai' (GM, BRV) & $x$ & $\times$ & $x$ & $\times$ & $\times$ & & $\times$ & $\times$ & & $\times$ & & 8 \\
\hline 'Minaj Shmyriov’ (GM) & $x$ & & $x$ & $\times$ & & & & $\times$ & & & & 4 \\
\hline 'Ritmo' (GM, BRV) & $x$ & $\times$ & $x$ & & & $\times$ & & $\times$ & & $\times$ & & 6 \\
\hline ‘Senjorai’ (BRV) & & & & $\times$ & & $\times$ & & & $x$ & $\times$ & $x$ & 6 \\
\hline ‘Smaliai’ (BRV) & & & & $\times$ & $x$ & $\times$ & & $\times$ & & $\times$ & & 6 \\
\hline ‘Viktor' (GM, BRV) & $x$ & $\times$ & $\times$ & $\times$ & & $x$ & $x$ & & & $\times$ & & 7 \\
\hline Hybrid 1 (BRV) & & $\times$ & & & $x$ & & & & $x$ & & & 3 \\
\hline Hybrid 2 (GM) & $x$ & & & & & & & & & & $x$ & 2 \\
\hline Hybrid 3 (GM, BRV) & $x$ & & & & & & $x$ & & & & & 2 \\
\hline Hybrid 4 (GM, BRV) & $x$ & & & & & $\times$ & $\times$ & & & & $x$ & 4 \\
\hline Hybrid 5 (BRV) & & & & & $x$ & & & & & & & 1 \\
\hline Hybrid 6 (BRV) & & & & & & & & & $\times$ & & & 1 \\
\hline R. americanum (GM) & $x$ & & $x$ & & & & & & & & & 2 \\
\hline R. aureum 'Brecht' (GM) & $\times$ & & $\times$ & $\times$ & & & & $\times$ & $\times$ & $\times$ & & 6 \\
\hline R. dikuscha (BRV) & & $\times$ & & & & & $\times$ & $\times$ & & $\times$ & & 4 \\
\hline R. nigrum ssp. sibiricum 'Rus' (GM, BRV) & $\times$ & $\times$ & & $\times$ & & $\times$ & $\times$ & $\times$ & & & $\times$ & 7 \\
\hline R. pauciflorum (BRV) & & & & $\times$ & & & & & $\times$ & & & 2 \\
\hline R. sanguineum $(\mathrm{GM})$ & & & & & & $\times$ & $\times$ & & $\times$ & $\times$ & & 4 \\
\hline R. uva-crispa (GM, BRV) & & $\times$ & $\times$ & & & & $\times$ & & $\times$ & & & 4 \\
\hline Total & 12 & 8 & 8 & 9 & 4 & 7 & 10 & 9 & 7 & 10 & 4 & 87 \\
\hline
\end{tabular}

In Ribes species the quantity of molecular markers varied between 2 and 7. Species $R$. americanum, $R$. aureum, $R$. dikuscha, $R$. nigrum ssp. sibiricum, $R$. pauciflorum, $R$. sanguineum and $R$. uva-crispa are known as donors of resistance to gall mite and/ or BRV (Anderson, 1971; Keep et al., 1982; Brennan, 2008; Stalažs, Moročko-Bičevska, 2016; Mazeikiene et al., 2017). The origin of resistance in $R$. dikuscha and $R$. pauciflorum was unknown as well as molecular markers. Specific markers for R. dikuscha (E40M43_236, E41M88_280, E40M40_219 and E45M40_222) and R. pauciflorum (E41M40_222 and E40M42_226) were found in this study.

AFLP markers are characterized by a moderate level of polymorphism in intra species studies (Ahmad et al., 2017), therefore markers obtained in bi-parental 
population studies (Brennan et al., 2008; Mazeikiene et al., 2012) were suitable for the analysis of most Ribes spp. genotypes in this research. Specific combinations of resistance molecular markers for species $R$. americanum, $R$. aureum, $R$. nigrum ssp. sibiricum, $R$. sanguineum and $R$. uva-crispa were found (Table 3 ) and could be used for marker-assisted selection in the future. No molecular markers were detected in $R$. hudsonianum and in hybrids 'Titania' $\times R$. rubrum 'Jonkher van Tets' $\mathrm{F}_{3}$ and 'Tauriai' $\times$ ('Titania' $\times R$. uva-crispa 'Bedford Yellow') $F_{2}$, although they had resistance to gall mite and BRV in field conditions. R. hudsonianum is known as a genetic donor of resistance (Brennan, 2008), but this study did not validate any molecular marker for this species. Genetic origin of $R$. hudsonianum resistance is still unclear and more researches in the future are required. Frequency of molecular markers in cultivars and hybrids was determined by targeted selection of resistant seedlings in hybridization process. We suggest that genetically determinate resistance to gall mite and BRV loci in promising donors must be recombined with several molecular markers.

Phylogenetic tree based on neighbour-joining unweighted analysis shows that the tested molecular markers grouped according to the dependence on resistance genes to C. ribis or BRV (Fig. 3). It was assumed that there are several resistance mechanisms available in Ribes species according to the data of clustering analysis. With reference to already known marker E41M88 208 (Brennan et al., 2009), marker E40M43 236 may be grouped in marker-assisted selection of resistance determined by gene $\mathrm{Ce}$. The marker E36M59_107 of gene $P$ (Mazeikiene et al., 2012) shows similarity of distribution in gall mite resistant genotypes with marker E40M43 289. Molecular markers E40M40 219 and E45M40 222 also can be used for identification of Ribes spp. genotypes with gene $P$. The reliability of selection is much greater when flanking markers are used (Pathania et al., 2017). According to the data of QTL by Brennan et al. (2008), marker E45M40 222 in combination with other investigated markers can flank the target locus of resistance. Markers E40M42_226, E41M41_163, g2J08 166, E4143 179 and E41M $40 \_222$ were specific for resistant genotypes, but were located in the third branch of the phylogenetic tree, separately from markers of genes $\mathrm{Ce}$ and $P$. We assume the presence of other resistance mechanisms in Ribes species and hybrids, which can be identified by markers from the third branch.

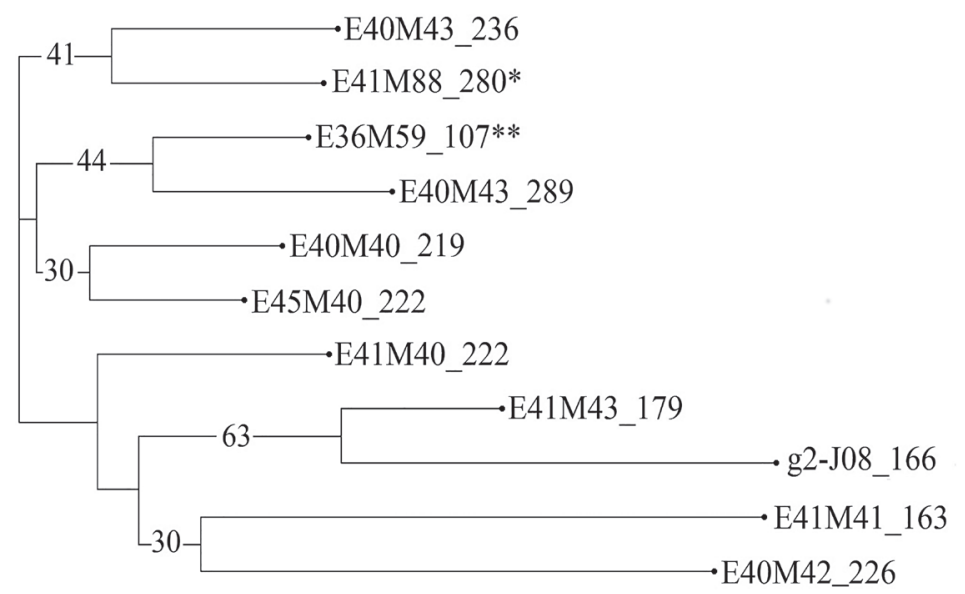

Note. Phylogenetic tree based on neighbour-joining unweighted analysis generated using the dissimilarity between units; * - the molecular marker of gene $C e$ (Brennan et al., 2009); ** - the molecular marker of gene $P$ (Mazeikiene et al., 2012).

Figure 3. Relationships of eleven molecular markers closely related to the pathogen and pest resistance

All investigated markers were selected from QTLs of bi-parental Ribes spp. populations (Brennan et al., 2008; 2009; Mazeikiene et al., 2012) and the data of these QTLs was transferred to Ribes spp. genotypes from different populations in our research. Results of this study showed that eleven investigated PCR markers could be used for the identification of resistant hybrids in different breeding populations according to genetic inheritance at this time. Data of similar scientific studies would be more reliable using meta-QTL of multiple populations and analyses need to be improved in the future (Ahmad et al., 2017). The investigated molecular markers of resistance to gall mite and BRV might be tested using a DNA sample without phenotyping in the field at this time. Assays of PCR markers are nondestructive for plants; therefore further comprehensive research of plant is possible.

\section{Conclusions}

1. A complex study of eleven molecular markers: E36M59_107, E40M43_236, E40M43_289, E41M40_222, E41M41_163, E41M43_179, E41M88_280, E40M40_219, E40M42 226, E45M40 222 and g2-J08 16 $\overline{6}$, reliably identifies Ribes spp. cultivars, species and hybrids with resistance to Cecidophyopsis ribis and Blackcurrant reversion virus (BRV).

2. Different origin of genetic resistance (genes $P$ and $C e$ or other) occurs in Ribes spp. genotypes according to the distribution of molecular markers, which can be determined without phenotyping.

3. The locus of resistance to gall mite, determined by gene $P$, had close recombination with E36M59 107, E40M43_289, E40M40_219 and E45M40_222. 
Molecular markers E40M43 236 and E41M88 280 are suitable for identification of gene $\mathrm{Ce}$. Other markers E40M42 226, E41M41 163, g2-J08 166, E4143 179 and E41M40_222 can be grouped together with already mentioned markers in breeding programs by markerassisted selection of resistant Ribes spp. genotypes.

Received 22012019

Accepted 10092019

\section{References}

1. Ahmad F., Akram A., Farman K., Abbas T., Bibi A., Khalid S., Waseem M. 2017. Molecular markers and marker assisted plant breeding: current status and their applications in agricultural development. Journal of Environmental and Agricultural Sciences, 11: 35-50.

2. Anderson M. M. 1971. Resistance to gall mite (Phytoptus ribis Nal.) in the eucoreosma section of Ribes. Euphytica, 20 (3): 422-426. https://doi.org/10.1007/BF00035668

3. Asins M. J., Bernet G. P., Villalta I., Carbonell E. A. 2010. QTL Analysis in plant breeding. Jain S. M., Brar D. S. (eds). Molecular techniques in crop improvement. Springer, p. 3-21.

https://doi.org/10.1007/978-90-481-2967-6_1

4. Brennan R. M. 2008. Currants and gooseberries. Hancock J. F. (ed.). Temperate fruit crop breeding: germplasm to genomics. Springer, p. 177-196. https://doi.org/10.1007/978-1-4020-6907-9_6

5. Brennan R., Jorgensen L., Hackett C., Woodhead M., Gordon S., Russell J. 2008. The development of a genetic linkage map of blackcurrant (Ribes nigrum L.) and the identification of regions associated with key fruit quality and agronomic traits. Euphytica, 161 (1-2): 19-34. https://doi.org/10.1007/s10681-007-9412-8

6. Brennan R., Jorgensen L., Gordon S., Loades K., Hackett C., Russell J. 2009. The development of a PCRbased marker linked to resistance to the blackcurrant gall mite (Cecidophyopsis ribis Acari: Eriophyidae). Theoretical and Applied Genetics, 118 (2): 205-211. https://doi.org/10.1007/s00122-008-0889-x

7. De Lillo E., Pozzebon A., Valenzano D., Duso C. 2018. An intimate relationship between eriophyoid mites and their host plants - a review. Frontiers in Plant Science, 9: 1-14. https://doi.org/10.3389/fpls.2018.01786

8. Doyle J. J., Doyle J. L. 1990. Isolation of plant DNA from fresh tissue. Focus, 12 (1): 13-15.

9. Hummer K. E., Dale A. 2010. Horticulture of Ribes. Forest Pathology, 40: 251-263.

https://doi.org/10.1111/j.1439-0329.2010.00657.x

10. Keep E., Knight V. H., Parker J. H. 1982. Progress in the integration of characters in gall mite (Cecidophyopsis ribis) resistant black currants. Journal of Horticultural Science, 57 (2): 189-196. https://doi.org/10.1080/00221589.1982.11515039

11. Martin R. R., Tzanetakis I. E. 2015. Control of virus diseases of berry crops. Advances in Virus Research, 91: 271-309.

https://doi.org/10.1016/bs.aivir.2014.10.003

12. Mazeikiene I., Bendokas V., Stanys V., Siksnianas T. 2012. Molecular markers linked to resistance to the gall mite in blackcurrant. Plant Breeding, 131 (6): 762-766.

https://doi.org/10.1111/j.1439-0523.2012.01995.x
13. Mazeikiene I., Bendokas V., Sasnauskas A., Juskyte A. D., Stanys V., Siksnianas T. 2017. Genetic background of resistance to gall mite in Ribes species. Agricultural and Food Science, 26 (2): 111-117.

https://doi.org/10.23986/afsci.59410

14. Mažeikienė I., Stanys V., Juškytė A. D., Sasnauskas A., Šikšnianas T. 2017. 'Aldoniai' and 'Didikai' varieties of black currant. Sodininkystè ir daržininkyste, 36 (1-2): 3-14 (in Lithuanian).

15. Palmieri L., Grando M. S., Sordo M., Grisenti M., Martens S., Giongo L. 2013. Establishment of molecular markers for germplasm management in a worldwide provenance Ribes spp. collection. Plant Omics Journal, 6 (3): 165-174.

16. Pathania A., Rialch N., Sharma P. N. 2017. Marker-assisted selection in disease resistance breeding. Dubey S. K. et al. (eds). Current developments in biotechnology and bioengineering. Elsevier, p. 187-214.

https://doi.org/10.1016/B978-0-444-63661-4.00009-8

17. Piotrowski W., Labanowska B. H., Galińska A., Cuthbertson A. G. S. 2016. Migration monitoring of blackcurrant gall mite (Cecidophyopsis ribis Westw.) from buds to leaves on several blackcurrant (Ribes nigrum L.) cultivars. Journal of Horticultural Research, 24 (2): 61-66. https://doi.org/10.1515/johr-2016-0021

18. Raudonius S. 2017. Application of statistics in plant and crop research: important issues. Zemdirbyste-Agriculture, 104 (4): 377-382. https://doi.org/10.13080/z-a.2017.104.048

19. Rubauskis E., Strautina S., Surikova V. 2006. Importance of cultivar choice in preventing infestation by the blackcurrant gall mite (Cecidophyopsis ribis Westw.) on blackcurrant plantations. Journal of Fruit and Ornamental Plant Research, 14 (3): 209-215.

20. Russell J. R., Bayer M., Booth C., Cardle L., Hackett C. A., Hedley P. E., Jorgensen L., Morris J. A., Brennan R. M. 2011. Identification, utilisation and mapping of novel transcriptome-based markers from blackcurrant (Ribes nigrum). BMC Plant Biology, 10: 147.

https://doi.org/10.1186/1471-2229-11-147

21. Šikšnianas T. 2005. Development of productive, resistant to fungal diseases and gall mite black currant cultivars. Sodininkystè ir daržininkystè, 24 (1): 16-24 (in Lithuanian).

22. Siksnianas T., Stanys V., Sasnauskas A., Viskelis P., Rubinskiene M. 2006. Fruit quality and processing potential in five new blackcurrant cultivars. Journal of Fruit and Ornamental Plant Research, 14 (2): 265-271.

23. Stalažs A., Moročko-Bičevska I. 2016. Species identification, host range and diversity of Cecidophyopsis mites (Acari: Trombidiformes) infesting Ribes in Latvia. Experimental and Applied Acarology, 69 (2): 129-153. https://doi.org/10.1007/s10493-016-0024-7

24. Vos P., Hogers R., Bleeker M., Reijans M., van de Lee T., Hornes M., Frijters A., Pot J., Peleman J., Kuiper M., Zabeaum M. 1995. AFLP: a new technique for DNA fingerprinting. Nucleic Acids Research, 23: 4407-4414. https://doi.org/10.1093/nar/23.21.4407 
ISSN 1392-3196 / e-ISSN 2335-8947

Zemdirbyste-Agriculture, vol. 106, No. 4 (2019), p. 359-366

DOI 10.13080/z-a.2019.106.046

\title{
Atsparumo serbentinei erkutei ir juodojo serbento reversijos virusui molekulinių žymeklių taikymas Ribes genties augalų selekcijoje
}

\author{
I. Mažeikienè ${ }^{1}$, A. D. Juškytė ${ }^{1}$, V. Stanys ${ }^{1,2}$ \\ ${ }^{1}$ Lietuvos agrarinių ir miškų mokslų centro Sodininkystès ir daržininkystès institutas \\ ${ }^{2}$ Vytauto Didžiojo universiteto Žemès ūkio akademija
}

\section{Santrauka}

Serbentinė erkutė (Cecidophyopsis ribis Westw.) yra juodojo serbento (Ribes nigrum L.) reversijos viruso (BRV) biologinis vektorius. Šie kenkèjai ir patogenai plačiai paplitę šalyse, kuriose yra juodujjų serbentų plantacijų. Ribes nigrum yra pirminis natūralus BRV šaltinis, tačiau viruso infekcija aptinkama ir kitose Ribes rūšyse. Kai kurios Ribes rūšys ir veislès yra atsparios C. ribis ir/ar BRV. Atsparumo mechanizmas ir genų struktūra nèra aiški, todèl vykdant juodojo serbento veislių atranką ieškoma jiems atsparių molekulinių žymeklių. Remiantis kiekybinių požymių lokusų (QTL) žemẻlapiais, Ribes spp. genotipuose nustatyta keletas molekulinių žymeklių, susijusių su atsparumu erkutei ir virusui. Šie žymekliai padeda paspartinti atsparių juodojo serbento veislių selekciją ir tada nebereikia augalu fenotipinio vertinimo.

Tirta 12 PGR (AFLP ir SSR) žymeklių, per 4-20 cM nutolusių nuo atsparumo serbentinei erkutei ir virusui lokusų. Tyrimo metu 11 iš jų pasirode tinkami atspariu genotipų atrankai. Molekulinių žymeklių ieškota 8 Ribes rūšyse, 15 hibridu ir 13 R. nigrum veisliu. Nustatyti specifiniai molekuliniai žymekliai atsparių erkutei ir virusui Ribes spp. genotipu atrankai. Ribes spp. genomuose nustatyta skirtinga genetinio atsparumo C. ribis ir BRV kilmè. Vienuolikos molekulinių žymeklių kompleksinis panaudojimas leido patikimai identifikuoti Ribes rūšsis, veisles ir hibridus su nevienodu genetiniu atsparumu. Jie gali būti naudojami vykdyti žymekliais paremtai selekcijai. Buvo nustatyti šeši molekuliniai žymekliai: E36M59 107, E40M43 236, E40M43 289, E40M40_219, E41M88 280 ir E45M40_222, tinkami identifikuoti Ribes spp. genotipams su $C e$ ir $P$ genais.

Reikšminiai žodžiai: atsparumas, molekulinis žymeklis, serbentinè erkute. 